\title{
- Médico Veterinário: competência e ética
}

\section{Veterinary: competence and ethics}

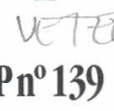

* Faculdade de Medicina Veterinária e Zootecnia - USP Departamento de Medicina Veterinária Preventiva e Saúde Animal. Av. Prof. Dr. Orlando Marques de Paiva, no 87 - CEP: 05508-000

São Paulo - SP

Tel.: (0xx11) 818-7653/

(0xx11) 7083-6001 R. 272

e-mail: malurigo@usp.br

Professora Doutora do Departamento de Medicina Veterinária Preventiva e Saúde Animal - FMVZ -

USP e do UNIFIEO - Centro Universitário FIEO - SP.

\section{RESUMO}

São analisadas as conceituações de competência e ética para a averiguação da permeabilização entre elas. Os dois tipos de éticas - a pessoal e a de negócios ou a da instituição - também são analisadas. Verifica-se a necessidade de equilíbrio entre elas para a obtenção do sucesso no mercado de trabalho. Conclui-se que a ética e a competência são dois fatores indispensáveis para o médico veterinário entrar, se manter e vencer no mercado de trabalho.

Palavras-chave: Medicina Veterinária, competência; ética.

$\underline{E}$ ntre os pré-requisitos necessários à carreira ou à formação de um veterinário, há que se destacar a competência e a ética.

Há algum tempo, a competência era traduzida pelo "saber fazer", definida no plano pessoal. FOGUEL e SOUZA (1985) afirmam que além dessa competência pessoal, deve existir a competência interpessoal, que "consiste no nível de habilidade de relacionamento entre as pessoas de uma organização". Isso significa que o médico veterinário de hoje necessita trabalhar em parceria, em equipe, além de ajudar os membros da instituição onde trabalha a resolver os problemas que se apresentem. Em 1997, RIOS afirmou que a competência tem um caráter político e um técnico que se interpenetram. O técnico distingue-se pelo "domínio do saber"; o político, pelo "querer" e pelo "poder fazer", que determinam a "intencionalidade de pôr em prática o conhecimento e a liberdade de direcionamento da ação".

Como resumiu LEAL (1999), competência é o "saber fazer bem", associado ao bom relacionamento interpessoal.

Em outras palavras, pode-se dizer que competência consiste em "querer e poder fazer bem" o "saber fazer bem", num ambiente de bom convívio entre as pessoas.

O outro pré-requisito, a ética, avalia a conduta do ser humano em relação a si e em relação aos outros.
Essa avaliação é feita sob a óptica do bem e do mal, de acordo com critérios geralmente ditados pela moral. Nesse aspecto, a ética confunde-se com a moral, que é o conjunto das prescrições de conduta admitidas em certa época e numa sociedade determinada. Entretanto, não se pode confundir ética e moral. NALINI (1997) explica bem essa distinção. Ética é a ciência do comportamento moral dos homens em sociedade. É uma ciência, uma vez que tem objeto, leis e métodos próprios. O objeto da ética é a moral, um dos aspectos do comportamento humano. Como ciência, a ética extrai dos feitos morais os princípios gerais a eles aplicáveis. Ainda de acordo com NALINI (1997), a ética é uma ciência normativa, não por criar normas, mas por descobri-las e elucidá-las, mostrando às pessoas os valores e os princípios que devem nortear sua existência.

SANCHEZ VASQUEZ (1998) define a moral como " um conjunto de normas e regras destinadas a regular as relações dos indivíduos numa comunidade social dada".

Com base nessas duas definições, verifica-se que, enquanto a ética se apresenta como uma reflexão crítica sobre a dimensão moral do comportamento do homem, a moral está ligada a interesses específicos de cada organização. Isto significa que tudo o que pode parecer natural e justo a uma coletividade qualquer, não o é necessariamente para outra. 
Ainda com base nas definições acima apresentadas, pode-se depreender que a ética é o elemento que permeia o "fazer bem", o "saber fazer bem", associado ao bom relacionamento interpessoal, pois ela dimensiona o comportamento moral a ser trilhado pelo indivíduo.

De acordo com os autores mencionados acima, não há receitas infalíveis para o caminho ético, mas sugestões que possam auxiliar na busca do desenvolvimento ético, tais como o exame de consciência, a revisão da escala de valores, a observância desses valores, e o reconhecimento à necessidade de um retorno à vida ética.

Para os indivíduos que desenvolvem uma atividade em uma instituição, em particular aquela de médico veterinário, existem dois tipos de ética: a pessoal (privada) e a conveniada (a da instituição). Assim, quando se analisa a ética, especialmente em instituições, verifica-se o surgimento de um tema denominado de "ética nos negócios". A "ética nos negócios", hoje, está presente em todas as áreas das instituições, o que não ocorria no passado, onde esse tema preocupava apenas alguns poucos dirigentes. Atualmente, muitas instituições empenham-se em encorajar a conduta ética em seus empregados. A expectativa é que empregados éticos tenham um comportamento ético no trabalho.

NASH (1993) explica o termo "ética nos negócios" como o estudo da forma pela qual as normas morais pessoais aplicam-se às atividades e aos objetivos da instituição; trata-se de harmonizar as questões vivenciadas nos negócios com aquelas próprias das pessoas que nelas trabalham, uma vez que os profissionais não têm necessariamente valores éticos idênticos.

NASH (1993) ainda alerta para alguns entraves de ordem ética existentes nas instituições e que podem ser transportados para a área médica veterinária: ganância, excesso de confiança no próprio julgamento (pondo em risco a instituição), má qualidade de serviço, humilhação das pessoas no trabalho, obediência cega às autoridades, não se importando se elas são antiéticas ou injustas, auto-engrandecimento, favoritismo, sacrifício do inocente e do mais fraco, bajulação em relação aos superiores hierárquicos e a busca de ascensão na escada corporativa, valendo-se dos menos favorecidos como degraus.

Para se ter uma conduta ética no mercado de trabalho, é necessário que as duas éticas - a pessoal e a dos negócios - sejam usadas equilibradamente, mantendo-se a convicção de que não se é apenas um cidadão particular e nem apenas um elo moral de uma instituição. Com esta estratégia, os valores e as obrigações da instituição e aqueles dos indivíduos serão mais bem combinados e poderão ser evitados possíveis conflitos entre a ética pessoal e a da instituição.

As grandes transformações que estão ocorrendo com a globalização trazem, como conseqüência, uma competitividade selvagem no mercado de trabalho. Para o médico veterinário entrar e manter-se nesse mercado de trabalho, há que se ter, como alicerces, a competência e a ética.

\section{SUMMARY}

In order to determine their permeation, the competence and ethics concepts are analysed. Two types of ethics - the personal and that related to the business or institution setting - are also discussed. In order to succeed in the labor market, a balance between competence and ethics has to be found, and therefore it can be concluded that both are indispensable for the veterinarian to get into, remain in and be successful in it.

Key words: competence; ethics.

\section{REFERÊNCIAS BIBLIOGRÁFICAS}

1 - FOGUEL, S.; SOUZA, C. C. Desenvolvimento e deterioração organizacional. 2.ed.. São Paulo: Atlas, 1985

2 - LEAL, C. Ser essencial: construção da nova competência. In: FÓRUM PAULISTA DE SECRETÁRIAS DO ESTADO DE SÃO PAULO, 3. Águas de São Pedro, 1999. Palestras.

3 - NALINI, J. R. Ética geral e profissional. São Paulo: Revista dos Tribunais, 1997.
4 - NASH, L. L. Ética nas empresas: boas intenções à parte. São Paulo: Makron Books, 1993.

5 - RIOS, T. A. Ética e competência. 5.ed. São Paulo: Cortez, 1997. (Coleção Questões da Nossa Época, v.16)

6 - SÁNCHEZ VÁSQUEZ, A. Ética. 18.ed. Rio de Janeiro: Civilização Brasileira, 1998. 